(C) Inra/Elsevier, Paris

Original article

\title{
Simulation of the maximum yield of sugar cane at different altitudes: effect of temperature on the conversion of radiation into biomass
}

\author{
Jean-François Martiné $\mathrm{a}^{*}$, Pierre Siband $^{\mathrm{b}}$, Raymond Bonhomme ${ }^{\mathrm{c}}$ \\ ${ }^{\text {a }}$ CIRAD-CA Station de la Bretagne, BP 20, 97408 Saint-Denis cedex 9, France \\ ${ }^{\mathrm{b}}$ CIRAD-CA 2477, avenue du Val de Montferrand, BP 5035, 34032 Montpellier cedex 1, France \\ ${ }^{\mathrm{C}}$ Unité de recherche en bioclimatologie, Inra, 78850 Thiverval-Grignon, France
}

(Received 15 March 1998; accepted 8 December 1998)

\begin{abstract}
To minimize the production costs of sugar cane, for the diverse sites of production found in La Réunion, an improved understanding of the influence of temperature on the dry matter radiation quotient is required. Existing models simulate poorly the temperature-radiation interaction. A model of sugar cane growth has been fitted to the results from two contrasting sites (mean temperatures: $14-30{ }^{\circ} \mathrm{C}$; total radiation: $10-25 \mathrm{MJ} \cdot \mathrm{m}^{-2} \cdot \mathrm{d}^{-1}$ ), on a ratoon crop of $\mathrm{cv}$ R570, under conditions of non-limiting resources. Radiation interception, aerial biomass, the fraction of millable stems, and their moisture content, were measured. The time-courses of the efficiency of radiation interception differed between sites. As a function of the sum of day-degrees, they were similar. The dry matter radiation quotient was related to temperature. The moisture content of millable stems depended on the day-degree sum. On the other hand, the leaf/stem ratio was independent of temperature. The relationships established enabled the construction of a simple model of yield potential. Applied to a set of sites representing the sugar cane growing area of La Réunion, it gave a good prediction of maximum yields. (@ Inra/Elsevier, Paris.)
\end{abstract}

sugar cane / plant growth model / dry matter radiation quotient / temperature

Résumé - Simulation du rendement maximal de la canne à sucre à différentes altitudes : effet de la température sur la conversion du rayonnement en biomasse. Optimiser les coûts de production de la canne à sucre, dans la diversité des situations de la Réunion, nécessite une meilleure compréhension de l'influence de la température sur le facteur de conversion du rayonnement intercepté en biomasse. Les modèles existants simulent mal l'interaction température-rayonnement. On a ajusté un modèle de croissance de la canne à sucre sur les résultats de deux sites contrastés (températures moyennes : $14-30^{\circ} \mathrm{C}$; rayonnement global: $10-25 \mathrm{MJ}^{-\mathrm{m}^{-2}} \mathrm{j}^{-1}$ ), sur une repousse du $\mathrm{cv} \mathrm{R} 570$, en condi-

Communicated by John E. Sheehy (Manila, Philippines)

* Correspondence and reprints

E-mail: martine@cirad.fr

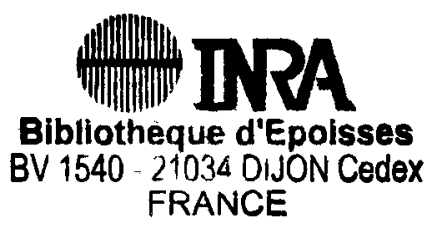


tions de ressources non limitantes. L'interception du rayonnement, la biomasse aérienne, la part de tiges usinables, et leur humidité ont été mesurées. Les progressions dans le temps de l'efficience d'interception du rayonnement diffèrent entre sites. En fonction de la somme des degré-jour elles sont similaires. Le facteur de conversion du rayonnement intercepté en biomasse dépend de la température. L'humidité des tiges usinables est déterminée par la somme des degré-jour. En revanche, le rapport feuilles/tiges est indépendant de la température. Les relations établies permettent de construire un modèle de potentiel simple. Appliqué à un jeu de situations qui représentent la zone de culture de canne de la Réunion, il prédit bien les rendements maximaux. (@ Inra/Elsevier, Paris.)

canne à sucre / modèle de croissance / facteur de conversion du rayonnement / température

\section{INTRODUCTION}

The production costs of sugar from cane are high, and very sensitive both to management decisions and the duration of the harvesting period. This emphasises the importance of farm inputs and of the factory infrastructures needed for a given production. Their optimisation is an important factor.

In La Réunion, cane yield varies from 30 to $180 \mathrm{t} \cdot \mathrm{ha}^{-1} \cdot$ year $^{-1}$. Harvesting lasts 4-5 months. The diversity of agricultural sites offers great scope for improvements, but makes the optimization of production difficult. A strictly experimental approach to this crop is particularly expensive, slow and unsuitable for dealing with climatic variation. Recourse to simulation reduces the need for experimentation and helps with the formulation of localized solutions. Development of a model should be facilitated by the simplicity of the plant and the wide range of accessible sites.

The literature contains various models of sugar cane growth, such as Auscane [8] and Canegro [7]. These models seem well adapted to the conditions under which they were developed. Their application to the contrasting sites of La Réunion has, however, proved to be difficult, calibration parameters differing from site to site $[2,12]$.

The main differences between sites being largely attributable to temperature and radiation, one is led to suppose that these models fail to treat the interaction between these two climatic parameters satisfactorily.

Thus, in the majority of studies where the range of variation in temperature is limited, or does not involve low temperatures, the conversion factor of radiation into biomass is assumed constant. This is indeed observed for sorghum [15], millet [22], maize and other cereals [9], and sugar cane $[6,16$, 19]. However, in colder climates, similar studies performed on maize [1] and sorghum [4] have shown a fall in conversion factor below a certain temperature. Robertson et al. [18] and Liu and Kingston [10] introduced into their models a function for the response of photosynthesis to temperature.

To take account of such climatic variations in the conditions of La Réunion, we set out to redefine a simple model, notably formalizing the effect of low temperatures on the dynamics of radiation interception, on the conversion of intercepted radiation into biomass and on the partition of the aerial biomass.

Sugar cane is a perennial crop which is periodically replanted, after which it is cut and successively ratooned annually in La Réunion. The area of planted cane being four times less than that of the ratoon crop, we will be mainly concerned with the latter, and with the main variety on the island, namely R570.

\section{MATERIALS AND METHODS}

\subsection{Model}

Incident photosynthetically active radiation PAR is calculated from incident total radiation Rt [21]:

$$
\mathrm{PAR}=0.5 \times \mathrm{Rt}
$$


The model comprises three major physiological processes:

- the interception of incident photosynthetically active radiation PAR, a function of the interception efficiency $\varepsilon i$, defined by Varlet-Grancher et al. [24] as the ratio of the radiation intercepted by the crop, PARi, and the PAR;

- the conversion of PARi into dry weight of aerial biomass $\mathrm{AB}$; a function of the dry matter radiation quotient (DMRQ, defined by Russel [20] and often incorrectly called radiation use efficiency, RUE);

- the partition of this aerial biomass $A B$ into dry weight of millable cane (MMC), a function of the Harvest Index HI; HI depends on the variable fraction of dry weight of stem $(\mathrm{SM})$ in $\mathrm{AB} ; \mathrm{SM}=\mathrm{f}(\mathrm{AB})$, and on the variable fraction of $\mathrm{MMC}$ in $\mathrm{SM}: \mathrm{MMC}=\mathrm{g}(\mathrm{SM})$.

It will be assumed that the fraction of assimilates allocated to roots is constant $[23,5]$.

Every day (d):

$$
\begin{gathered}
\mathrm{PAR}_{\mathrm{d}} \rightarrow \mathrm{PARi}_{\mathrm{d}} \rightarrow \Delta \mathrm{AB}_{\mathrm{d}} \rightarrow \Delta \mathrm{MMC}_{\mathrm{d}} \\
(\text { (i) } \quad(\mathrm{DMRQ}) \quad(\mathrm{HI}) \\
\mathrm{AB}_{\mathrm{d}}=\mathrm{AB}_{\mathrm{d}-1}+\Delta \mathrm{AB}_{\mathrm{d}} \\
\mathrm{MMC}_{\mathrm{d}}=\mathrm{MMC}_{\mathrm{d}-1}+\Delta \mathrm{MMC}_{\mathrm{d}}
\end{gathered}
$$

Every day, to computation of the useful yield $Y$, at the actual moisture content, from the dry weight of millable cane MMC is obtained by taking account of the moisture content $\left(\% \mathrm{H}_{2} \mathrm{O}\right)$ on fresh weight basis:

$$
\mathrm{Y}=\mathrm{MMC} \times 100 /\left(100-\% \mathrm{H}_{2} \mathrm{O}\right)
$$

Thus, we need to determine $\varepsilon \mathrm{i}, \mathrm{DMRQ}, \mathrm{HI}$ and \% $\mathrm{H}_{2} \mathrm{O}$.

\subsection{Experiments}

Three experiments served to define the relationships which make up the model. A set of independent results was available to test the model.
The experiments, each consisting of two plots of 195-225 $\mathrm{m}^{2}$ with the same cropping system, were carried out at two sites: Ligne Paradis $(150 \mathrm{~m}$ in altitude on a stony brown soil) and Colimaçons ( $780 \mathrm{~m}$ in altitude on a non-perhydrated andosol), situated at 21.3 and $21.1^{\circ} \mathrm{S}$ latitude, 55.5 and $55.3^{\circ} \mathrm{E}$ longitude, respectively. The experiments of Ligne Paradis (LP1 and LP2) and Colimaçons (CO) are described in table I.

The crop was a first ratoon of $\mathrm{cv}$ R570; the rows were $1.5 \mathrm{~m}$ apart. The fertilizer applied was $210 \mathrm{~kg} \mathrm{~N}, 70 \mathrm{~kg}$ $\mathrm{P}_{2} \mathrm{O}_{5}$ and $270 \mathrm{~kg} \mathrm{~K} 2 \mathrm{O}$ per hectare. The nitrogen was applied as four dressings, the potassium as three and the phosphorus as one, during the first 6 months. Soil moisture content was maintained at a level above $2 / 3$ of the available water content $\mathrm{AWC}$ by trickle irrigation.

To test the model, we used the cane yields (18 observations) from plots of tests of potential yields. The experimental sites were at Trois Bassins ( $\mathrm{TB}$, altitude $990 \mathrm{~m}$ ), Piton St. Leu (PSL $565 \mathrm{~m}$ ), Leroy (LR $500 \mathrm{~m}$ ), Ligne Paradis (LP $150 \mathrm{~m}$ ) and Tirano (TIR $150 \mathrm{~m}$ ). The plots were optimally trickle irrigated and liberally fertilized. We used the results from the first and second ratoons of the variety $\mathrm{R} 570$.

\subsection{Procedure and measurements}

\subsubsection{Radiation measurements}

The daily incident total radiation (Rt) was measured every day with a Kipp \& Zonen CM5 radiation pyranometer. The daily minimum (Tn) and maximum (Tx) temperatures were measured with a Cimel Electronique platinum resistance temperature probe. The data were recorded using Cimel 407 data logger. The daily incident photosynthetically active radiation (PAR) was measured with a Li-Cor cell type 190SB50 placed above the canopy.

The daily transmitted photosynthetically active radiation (PARt) was measured using a 30-cell amorphous silicon Solem PAR-IR/M placed under the canopy [3].

Table I. Standard conditions.

\begin{tabular}{lccc}
\hline & Growth period & Plot size & Crop measurements (number of dates) \\
\hline Colimaçons CO & $8 / 94-10 / 95$ & 10 rows of $13 \mathrm{~m}$ & AB, SM, MMC, \% $\mathrm{H}_{2} \mathrm{O}, \mathrm{Y}(7) \varepsilon \dot{(4)}$ \\
Ligne Paradis LP1 & $8 / 94-10 / 95$ & 10 rows of $15 \mathrm{~m}$ & AB, SM, MMC, \% $\mathrm{H}_{2} \mathrm{O}, \mathrm{Y}(5) \varepsilon i(5)$ \\
Ligne Paradis LP2 & $11 / 94-11 / 95$ & 10 rows of $15 \mathrm{~m}$ & $\varepsilon \mathrm{i}(2)$ \\
\hline
\end{tabular}


These Solem cells were fixed on six rails (five cells per rail) such that each rail covered half an inter-row space $(75 \mathrm{~cm})$. The six rails were arranged on each side of the observation line [11]. The PAR and PARt were measured over a complete day.ci and PARi were finally calculated by:

$$
\begin{gathered}
\varepsilon i=1-(\text { PARt/PAR }) \\
\text { PARi }=\varepsilon i \times \text { PAR }
\end{gathered}
$$

\subsubsection{Biomass measurements}

In order to follow the evolution of biomass over the same group of plants throughout the whole experiment, at each measurement date (table $I$ ) and on each plot:

- the height of every stem was measured on two $9-\mathrm{m}^{2}$ quadrats;

- outside these quadrats, a destructive sample was taken of $30-50$ stems.

This sample was separated into five lots of different heights, treated separately. On each lot, the fraction which had completed its growth was separated (hard millable stems); also the non-millable stem fraction, living leaves, and dead leaves. For all these fractions, fresh and dry weight were measured. Statistical relationships were established between height and total mean dry mass per stem $(\mathrm{AB})$ per lot, and between the dry weights of the various fractions;

- the biomasses corresponding to each $9-\mathrm{m}^{2}$ quadrat were then estimated using these relationships [11].

The cane yield used to test the model was measured on plots of $200-300 \mathrm{~m}^{2}$.

\subsection{Treatment of data}

\subsubsection{Determination of $\varepsilon i$}

The relationship was established between the temperature (day-degree sum) and the observed efficiency of radiation interception $\varepsilon$ i. It was fitted using non-linear regression.

\subsubsection{Determination of $D M R Q$}

The values of DMRQ ( $\triangle \mathrm{AB} / \mathrm{PARi})$ were calculated between two dates of biomass measurement; their varia- tion over time was related to the mean meteorological variables for the same time intervals: in particular with the mean air temperature $\mathrm{Tm}$ calculated as $(\mathrm{Tn}+\mathrm{Tm}) / 2$.

The methods and statistical parameters used were: the correlation coefficient ( $\mathrm{r}$ ) and analysis of variance (Fisher's test: probability $P$ ) for calibrating the model; a threshold of acceptability (boundary line of adequacy) for validation of the model [14].

\section{EXPERIMENTAL RESULTS AND PARAMETERIZATION OF THE MODEL}

\subsection{Climatic conditions}

Figures 1 and 2 show the main climatic variables applicable to the experiments, expressed as 10-day means. Over the whole experiment, the mean daily temperature varied from 14 to $30^{\circ} \mathrm{C}$, and the mean daily radiation from 10 to $25 \mathrm{MJ} \cdot \mathrm{m}^{-2}$. These ranges of variation define the limits of applicability of the study.

\subsection{Radiation interception}

The dynamics of the trend of $\varepsilon i$ as a function of duration of growth (figure 3) are of similar shape, but quite distinct for the three experiments. A value of 0.7 corresponds to the beginning of canopy closure, and the start of senescence on the youngest tillers. It is reached from the fourth month at low altitudes (LP1), and probably even a month earlier on LP2, whilst it takes nearly 6 months at high altitude $(\mathrm{CO})$. The interception efficiencies still differ after 8 months' growth.

Since $\varepsilon i$ is directly dependent on the leaf area index (LAI), whose time-course is often related to the day-degree sum $\left(\mathrm{SDD}_{12}\right)$, we have converted the time into these units. The best fit is obtained with a base temperature (Tbase) of $12{ }^{\circ} \mathrm{C}$. This temperature is similar to that which we find from analyses of the rates of leaf appearance (phyllochrone) and stem elongation. The literature does not contain values for the base temperature for LAI develop- 


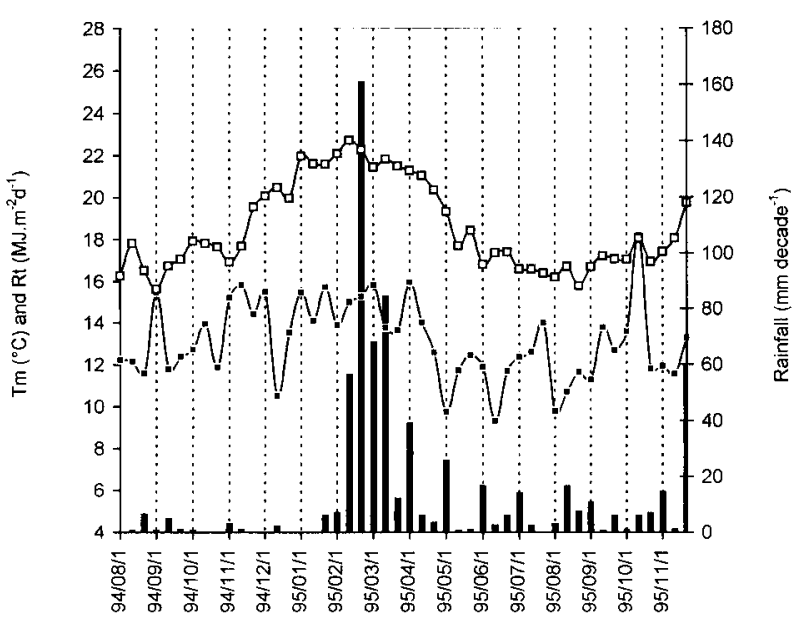

Year/Month/Decade

Figure 1. Colimaçons: rainfall (I), total radiation (Rt $\mathbf{a}$ ) and mean temperature (Tm $\square)$ for the decade August 1994-November 1995.

Y-axis left: $\mathrm{Tm}\left({ }^{\circ} \mathrm{C}\right)$ and $\mathrm{Rt}\left(\mathrm{MJ} \cdot \mathrm{m}^{-2} \cdot \mathrm{d}^{-1}\right) ; \mathrm{Y}$-axis right: rainfall $\left(\mathrm{mm} \cdot \mathrm{decade}^{-1}\right)$; X-axis: year/month/decade.

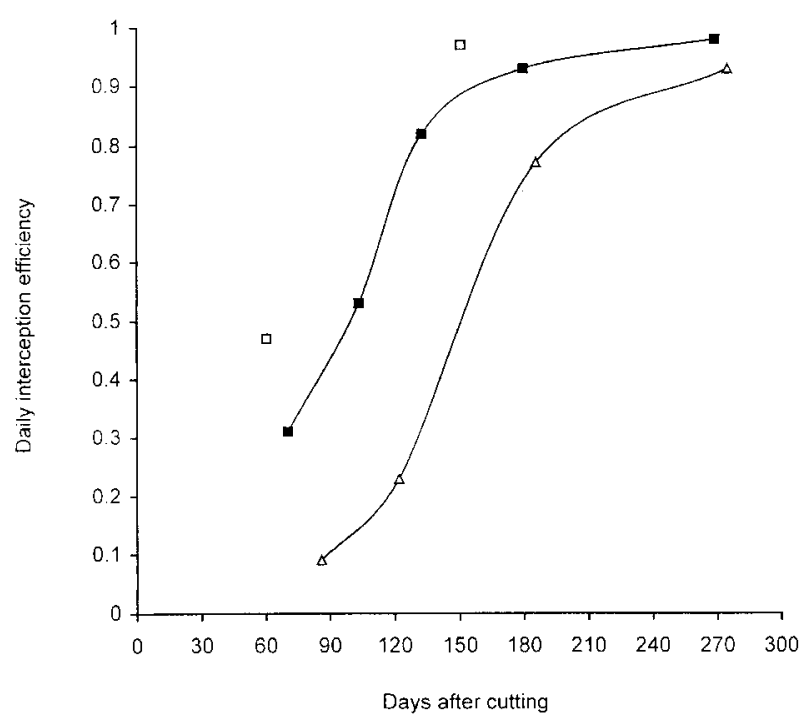

Figure 3. Comparison between daily interception efficiency ( $\varepsilon$ i) observed at Colimaçons $(\mathrm{Co}-\Delta)$ and Ligne Paradis (LP1 and LP2 $\square$ ).

$\mathrm{Y}$-axis: daily interception efficiency; $\mathrm{X}$-axis: days after cutting.

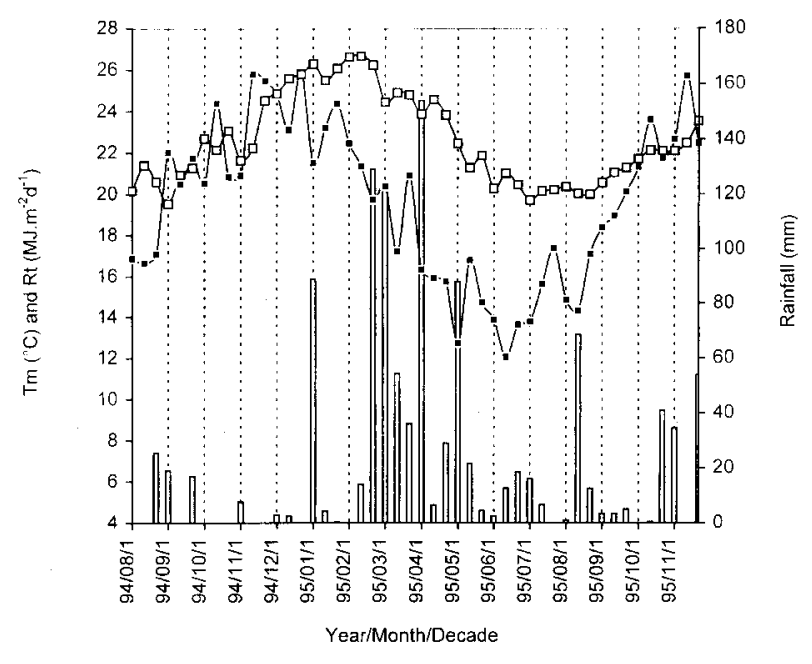

Figure 2. Ligne Paradis: rainfall (D), total radiation (Rt $\mathbf{\square})$ and mean temperature (Tm $\square)$ for the decade August 1994-November 95.

Y-axis left: $\mathrm{Tm}\left({ }^{\circ} \mathrm{C}\right)$ and $\mathrm{Rt}\left(\mathrm{MJ} \cdot \mathrm{m}^{-2} \cdot \mathrm{d}^{-1}\right)$; Y-axis right: rainfall $\left(\mathrm{mm} \cdot \mathrm{decade}^{-1}\right) ; \mathrm{X}$-axis: year/month/decade.

ment. The tbase values for the sugar cane phyllochrone vary from 10 to $12{ }^{\circ} \mathrm{C}[6,17,25]$.

When the data are plotted against accumulated day-degrees (figure 4), the points representing $\varepsilon \mathrm{i}$ fall on a single line, which fits a simple Gompertz curve with a coefficient of correlation of $0.999(P<$ $0.001)$.

\subsection{Conversion of intercepted radiation into biomass (DMRQ)}

The DMRQ ( $\triangle \mathrm{AB} / \mathrm{PARi}$ ), established between two measurement dates seem to decrease with the age of the crop (figure 5a), although the relationship is not significant $(\mathrm{r}=0.61, P=0.06)$.

However, these variations are essentially due to the difference in rate of development between the measurements at LP (high temperatures, figure 2) and $\mathrm{CO}$ (lower temperatures, figure 1). 


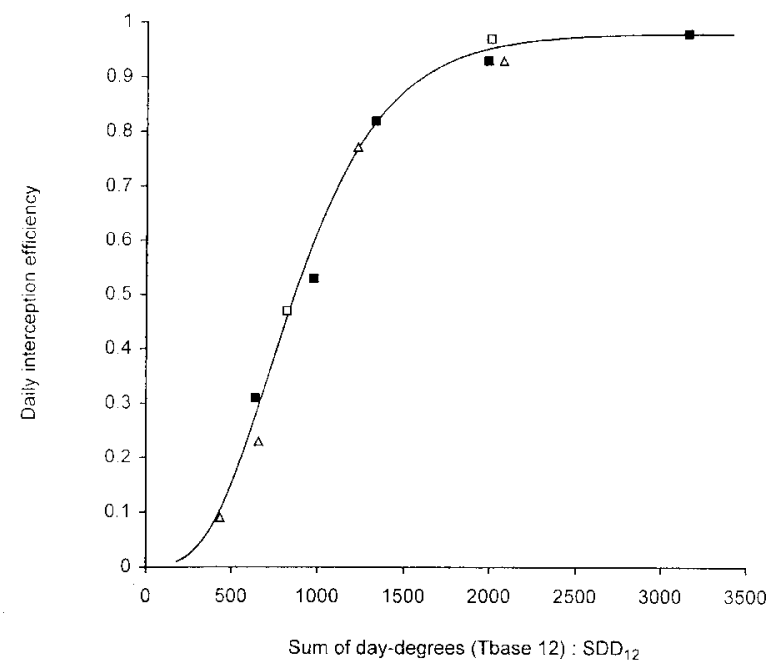

Figure 4. Relationship between sum of day-degrees (Tbase $12{ }^{\circ} \mathrm{C}$ ) and daily interception efficiency (ci) observed at Colimaçons (CO $\Delta$ ) and Ligne Paradis (LP1 $\square$ and LP2 $\square$ ). The regression formula was $\varepsilon \mathrm{i}=0.98 \times \exp (-5.71 \times$ $\exp (-0.0028 \times($ SDD12-100)) $), \mathrm{r}=0.999$.

$\mathrm{Y}$-axis: daily interception efficiency; $\mathrm{X}$-axis: sum of daydegrees (Tbase 12): $\mathrm{SDD}_{12}$.

As well as this temperature difference between sites, there was a fall in temperature towards the end of the growing period. These two variations resulted in a significant relationship between DMRQ and the mean temperatures over the corresponding periods as shown in figure $5 b$. This relationship has the equation:

$$
\begin{gathered}
\mathrm{DMRQ}=0.107 \times \mathrm{Tm}+0.76 \\
(\mathrm{r}=0.74 ; P=0.015)
\end{gathered}
$$

and thus leads in our range of measurements to values between $2.38 \mathrm{~g} \cdot \mathrm{MJ}^{-1}$ (PARi) at $15^{\circ} \mathrm{C}$ and $3.55 \mathrm{~g} \cdot \mathrm{MJ}^{-1}(\mathrm{PARi})$ at $26^{\circ} \mathrm{C}$.

This variation in DMRQ with temperature has already been observed for maize [1] and sorghum [15] but not for sugar cane. However, the low values of DMRQ seen in figure 4 in Muchow et al. [16] correspond to lower temperatures at the beginning and end of growth. A rigorous comparison with the results of Muchow et al. [16] and Robertson et al. [19] is thus not possible, since these authors used a questionable procedure which relates cumulative
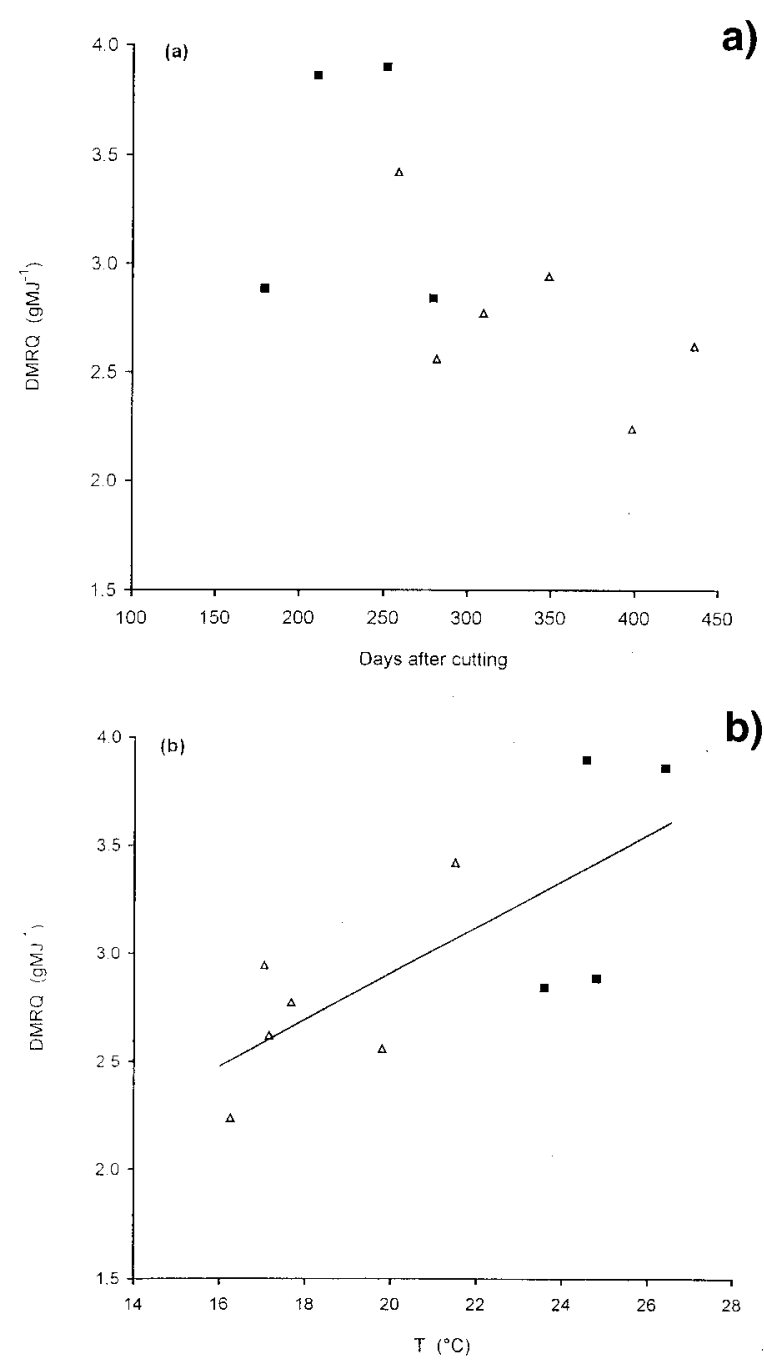

Figure 5. Relationships between days after cutting (a) or Mean air temperature $\mathrm{T}$ (b) and dry matter radiation quotient (DMRQ) observed at Colimaçons (CO $\Delta$ ) and Ligne Paradis (LP1 $\square$ ). The regression formula in (b) was DMRQ $=0.107 \times$ $T+0.76, r=0.74$.

$\mathrm{Y}$-axis: DMRQ $\left(\mathrm{g} \cdot \mathrm{MJ}^{-1}\right)$; $\mathrm{X}$-axis (figure $\left.5 \mathrm{a}\right)$ : days after cutting; $\mathrm{X}$-axis (figure $5 \mathrm{~b}): \mathrm{T}\left({ }^{\circ} \mathrm{C}\right)$.

biomass with cumulative total intercepted radiation. But the orders of magnitude of DMRQ obtained in our conditions are comparable to the values obtained by these authors (from 1.59 to $1.75 \mathrm{~g} \cdot \mathrm{MJ}^{-1}$ (Rt intercepted)) which must be multiplied by a value slightly inferior to 2 .

The comparison between the observed values of $\mathrm{AB}$ and those simulated by the model (equation 8 ) 
shows that a fairly constant difference exists between observed and simulated AB (figure 6). The mean difference between observed and simulated $A B$ is $700 \pm 80 \mathrm{~g} \cdot \mathrm{m}^{-2}$. This bias is due to the basal part (stem and leaf), underground and not measured, of the cane formed especially at the beginning of growth. The measurable aerial dry matter $A B$ can thus be found from the equation:

$$
\mathrm{AB}=\Sigma(\mathrm{DMRQ} \times \mathrm{PARi})-700
$$

\subsection{Partition of the aerial biomass (HI)}

\subsubsection{Growth of stems}

Figure 7 shows the variation of $\triangle \mathrm{SM} / \triangle \mathrm{AB}$ as a function of $\mathrm{AB}$. The values which come from two sites fall on the same line. The fraction allocated to stem increases linearly up to $1.8 \mathrm{~kg} \cdot \mathrm{m}^{-2}$ of $\mathrm{AB}$, after which it tends to fall very slightly.

For the sake of simplicity of the model, and considering the imprecision attached to the small gradient of the second part of the relation, we will adopt the following equations:

$$
\Delta \mathrm{SM} / \triangle \mathrm{AB}=0.00042 \times \mathrm{AB}
$$

with $\Delta \mathrm{SM} / \Delta \mathrm{AB}=0.75$ if $\mathrm{AB}>1800 \mathrm{~g} \cdot \mathrm{m}^{-2}$.

The error in calculating SM never exceeds $5 \%$.

\subsubsection{Millable stems}

The linear relation between the observed values of MMC and SM is highly significant (MMC $=1.0$ $\times \mathrm{SM}-140, \mathrm{r}=0.999, P<0.001)$. The equation which can be used to calculate the millable cane dry matter is the following:

$$
\mathrm{MMC}=\mathrm{SM}-140
$$

\subsection{Trend of actual stem moisture content}

The percent of water fell over the course of time. The best fit (figure 8) was obtained by using the

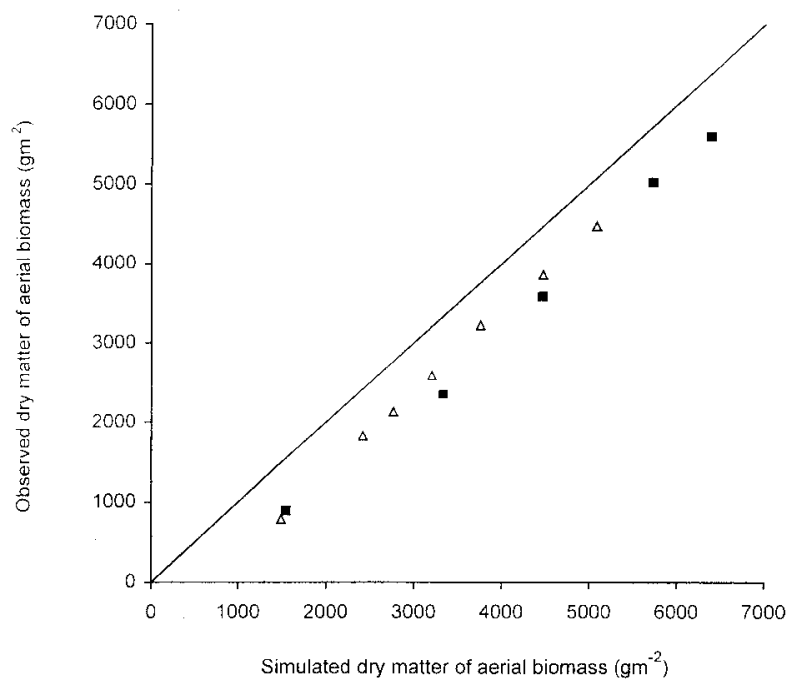

Figure 6. Relationship between simulated and observed dry matters of aerial biomass observed at Colimaçons (Co $\Delta$ ) and Ligne Paradis (LP1 $\mathbf{\square}$ ). The 1:1 line is shown.

$\mathrm{Y}$-axis: observed dry matter of aerial biomass $\left(\mathrm{g} \cdot \mathrm{m}^{-2}\right)$; $\mathrm{X}$-axis: simulated dry matter of aerial biomass $\left(\mathrm{g} \cdot \mathrm{m}^{-2}\right)$.

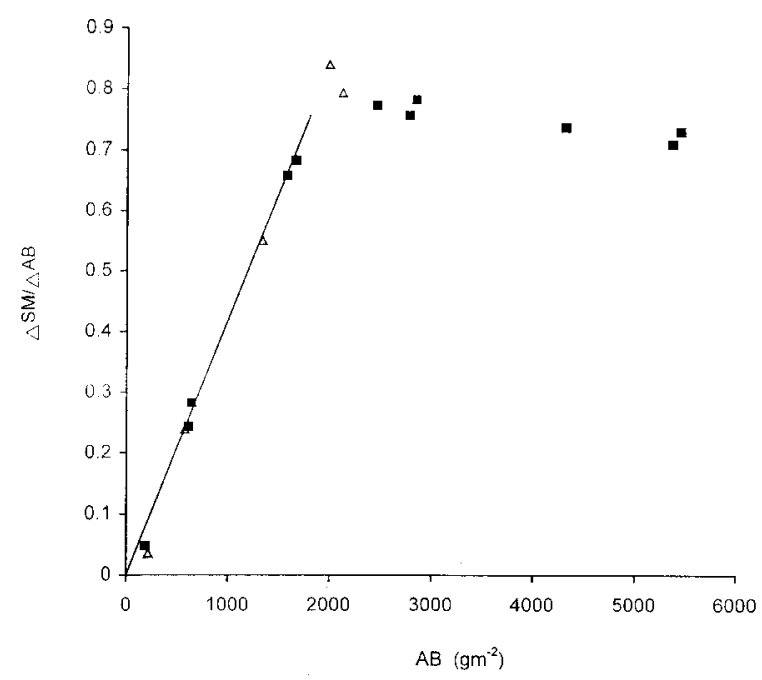

Figure 7. Relationship between aerial biomass produced since cutting $(\mathrm{AB})$ and the proportion of stem in the aerial biomass formed each day $(\triangle \mathrm{SM} / \triangle \mathrm{AB})$. The observation were made at Colimaçons $(\mathrm{Co} \Delta$ ) and Ligne Paradis (LP1 $\mathbf{\square}$ ). The regression formula was $\Delta \mathrm{SM} / \Delta \mathrm{AB}=0.00042 \times \mathrm{AB}, \mathrm{r}=0.999$. Y-axis: $\Delta \mathrm{SM} / \triangle \mathrm{AB} ; \mathrm{X}$-axis: $\mathrm{AB}\left(\mathrm{g} \cdot \mathrm{m}^{-2}\right)$.

sum (ST) of mean temperatures Tm since the previous harvest $(\mathrm{r}=0.97, P<0.001)$. It gives the fol- 


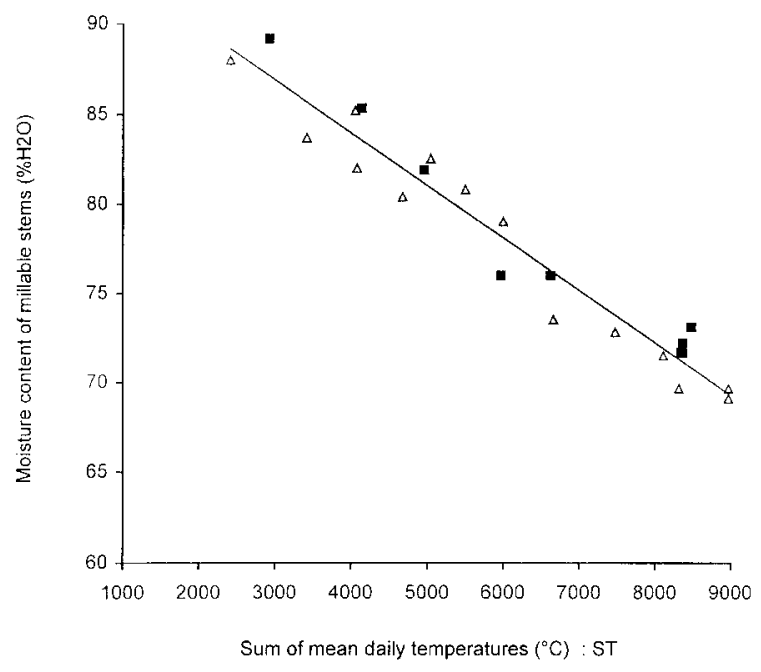

Figure 8. Relationship between the sum of mean daily temperatures (ST) since the previous cutting and the moisture content of millable stems $\left(\% \mathrm{H}_{2} \mathrm{O}\right)$. The observation were made at Colimaçons $(\mathrm{CO} \Delta)$ and Ligne Paradis (LP1 $\mathbf{\square})$. The regression formula was \% $\mathrm{H}_{2} 0=96-0.0029 \times \mathrm{ST}, \mathrm{r}=0.97$.

$\mathrm{Y}$-axis: moisture content of millable stems $\left(\% \mathrm{H}_{2} \mathrm{O}\right)$; X-axis: sum of mean daily temperatures $\left({ }^{\circ} \mathrm{C}\right)$ : ST.

lowing equation:

$$
\% \mathrm{H}_{2} \mathrm{O}=96-0.0029 \times \mathrm{ST}
$$

One might think that the $\mathrm{r}$ obtained is good enough for prediction. It is probable that $\% \mathrm{H}_{2} \mathrm{O}$ would depend on the moisture state of the crop, which superimposes rapid variations on this trend. This variation, however, appears to be too small to be attributed to water stress in our experiments. One would hope to improve the prediction of the agricultural yield by the introduction of the water balance into the model.

\section{TESTING THE MODEL}

The improved model can be applied to the set of sites reserved for its testing, by calculating the expected agricultural yield.

To evaluate the performance of the model we have used Mitchell's method [14] and have studied the deviations between observed and simulated yields with a threshold of acceptability of

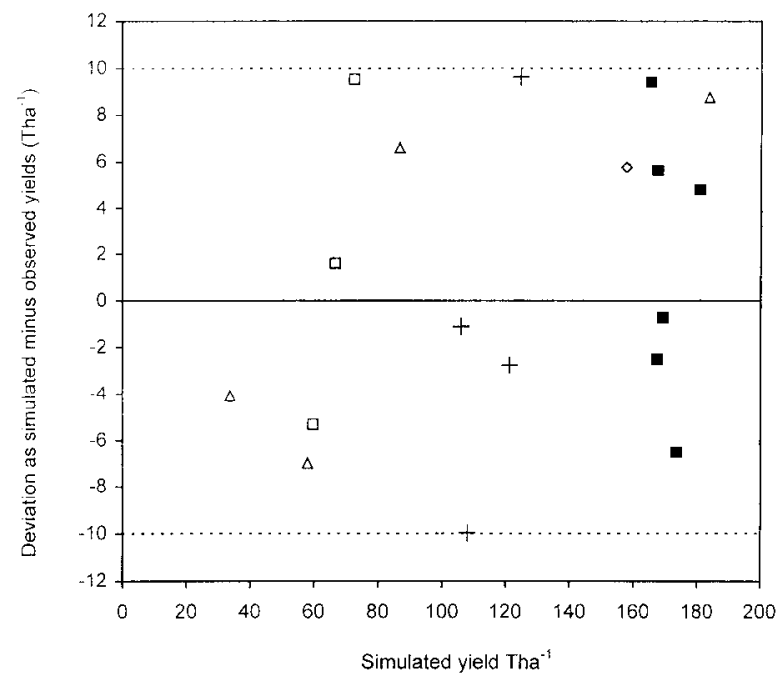

Figure 9. Relationship between deviation as simulated minus observed yields and simulated yields. Yields were observed at Tirano $(\Delta)$, Piton St Leu (+), Ligne Paradis $(\boldsymbol{E})$, Trois Bassins $(\square)$ and Leroy $(\diamond)$. The envelope of acceptable precision shown is $\pm 10 \mathrm{~T} \cdot \mathrm{ha}^{-1}$.

$\mathrm{Y}$-axis: deviation as simulated minus observed yields $\left(\mathrm{T} \cdot \mathrm{ha}^{-1}\right)$; $\mathrm{X}$-axis: simulated yield $\mathrm{T} \cdot \mathrm{ha}^{-1}$.

$\pm 10 \mathrm{~T} \cdot \mathrm{ha}^{-1}$. Figure 9, which shows the relation between the simulated yields and the deviations, shows that no deviation exceeds this threshold, and that there is no relation between the simulated yields and the deviations.

It appears that the model predicts well the maximum yields obtained over a range of altitudes which largely applies to the cane-growing area of La Réunion.

\section{DISCUSSION}

On the basis of a dataset from fairly contrasting sites, it has been possible to establish the different relationships needed to construct a simple model of the yield of a sugar cane crop with satisfactory precision.

All that was needed was the correction of the DMRQ by a temperature factor. This has lead to a great improvement in the estimation of this para- 
meter. This improvement makes possible predictions of yield close to those measured.

Inman-Bamber [5, 7] broke down the expression for the energy conversion term by distinguishing gross photosynthesis and growth and maintenance respiration. These respiration terms are also temperature dependent. Having only measured the net result of these processes, it seemed inopportune to us to attempt to calculate these parameters. However, the absence of a significant relation between DMRQ and age (increasing $A B$ ) shows that if the maintenance respiration has a bearing on this relation, it is not proportional to the elaborated biomass; also its distinction here does not appear as useful.

The interception efficiency $\varepsilon \mathrm{i}$, being fitted to the day-degree sum, is also temperature dependent, and contributes to the explanation of the site effect. The same applies to the moisture content of the millable stems. On the other hand, the partition of aerial biomass appears to be independent of temperature.

The decision to regard the production of root biomass as a constant proportion of aerial biomass appears to be acceptable. The aerial biomass situated below the soil (the stump), which was not measured and cannot be harvested, is considered to be constant in the model. Its value $\left(700 \mathrm{~g} \cdot \mathrm{m}^{-2}\right)$ is similar to values found in the literature [23].

The moisture content of the stems remains one of the least well fitted term in the model. This does not affect its capacity to predict, as the testing shows, inasmuch as it is a model for potential yield. This implies that the moisture content of the tissues is not greatly affected by the growing conditions. This term could be formulated with greater precision once the water stress is taken into account.

This model, which takes into account the interaction between radiation and temperature during yield formation, has allowed growth to be analysed, together with the yield potential in different climatic zones of La Réunion and for various cultural situations with different cutting dates and ages at harvest [13]. Depending on the climate and cutting date, the results enable the recommendation of different scenarios for weed control and irrigation, to identify the periods most sensitive to water and

nutrient stress, to estimate possible yield increases and thus to assess the advisability of investments.

\section{ABREVIATIONS}

Symbol Unit

$\% \mathrm{H}_{2} \mathrm{O} \%$

$\mathrm{AB} \quad \mathrm{g} \cdot \mathrm{m}^{-2}$

AWC $\mathrm{mm}$

DMRQ $g \cdot \mathrm{MJ}^{-1}$

$\triangle \mathrm{AB} \quad \mathrm{g} \cdot \mathrm{m}^{-2} \cdot \mathrm{d}^{-1}$

$\triangle M M C g \cdot \mathrm{m}^{-2} \cdot \mathrm{d}^{-1}$

$\triangle \mathrm{SM} \quad \mathrm{g} \cdot \mathrm{m}^{-2} \cdot \mathrm{d}^{-1}$

\&i fraction

HI fraction

LAI fraction

MMC $\mathrm{g} \cdot \mathrm{m}^{-2}$

PAR

PARi $\quad \mathrm{M} \cdot \mathrm{Jm}^{-2} \cdot \mathrm{d}^{-1}$

PARt $\mathrm{MJ} \cdot \mathrm{m}^{-2} \cdot \mathrm{d}^{-1}$ daily transmitted photosynthetically active radiation

Rt $\mathrm{MJ} \cdot \mathrm{m}^{-2} \cdot \mathrm{d}^{-1}$ daily total incident radiation

RUE $\mathrm{g} \cdot \mathrm{MJ}^{-1} \quad$ radiation use efficiency

$\mathrm{SDD}_{12}{ }^{\circ} \mathrm{C}$

$\mathrm{SM} \quad \mathrm{g} \cdot \mathrm{m}^{-2}$

ST ${ }^{\circ} \mathrm{C}$

Tbase ${ }^{\circ} \mathrm{C} \quad$ base temperature

Tm ${ }^{\circ} \mathrm{C}$

Tn $\quad{ }^{\circ} \mathrm{C}$

Tx $\quad{ }^{\circ} \mathrm{C}$

$\mathrm{Y} \quad \mathrm{T} \cdot \mathrm{ha}^{-1}$ (of intercepted radiation) sum of day-degrees (tbase 12) since previous cutting stem dry matter sum of daily mean air temperatures since previous cutting daily mean air temperature daily minimum air temperature daily maximum air temperature yield (millable cane fresh weight) 


\section{REFERENCES}

[1] Andrade F., Uhart S.A., Cirilo A., Temperature affects radiation use efficiency in maize, Field Crops Res. 32 (1993) 17-25.

[2] Bensimon G., Calibration et validation d'un modèle de simulation de la croissance et du développement de la canne à sucre à l'île de la Réunion, mémoire de DAA, Ensaia, Nancy, 1991.

[3] Chartier M., Bonchrétien P., Allirand J.M., Gosse G., Utilisation des cellules au silicium amorphe pour la mesure du rayonnement photosynthétiquement actif (400-700 nm), Agronomie 9 (1989) 281-284.

[4] Hammer G.L., Vanderlip R.L., Genotype by environment interaction in grain sorghum.1. Effects of temperature on radiation efficiency, Crop Sci. 29 (1989) $370-376$.

[5] Inman-Bamber N.G., A growth model for sugarcane based on a simple carbon balance and the CERESMaize water balance, S. Afr. J. Plant. Soil 8 (1991) 93-99.

[6] Inman-Bamber N.G., Temperature and seasonal effects on canopy development and light interception of sugarcane, Field Crops Res. 36 (1994) 41-51.

[7] Inman-Bamber N.G., CANEGRO: its history, conceptual basis, present and future uses, in: Proc. Research and Modelling Approaches to Examine Sugarcane Production Opportunities and Constraints, CSIRO, Brisbane, Australia, 1995, pp. 31-34.

[8] Jones C.A., Wegener M.K., Russell J.S., McLeod I.M., Williams J.R., AUSCANE - Simulation of Australian Sugarcane with EPIC, CSIRO, Brisbane, 1989.

[9] Kiniry J.R., Jones C.A., O'Toole J.C., Blanchet R., Cabelguenne M., Spanel D.A., Radiation use effíciency in biomass accumulation prior to grain filling for five grain crop species, Field Crops Res. 20 (1989) $51-64$.

[10] Liu D.L., Kingston G., QCANE: a simulation model of sugarcane growth and sugar accumulation, in: Proc. Research and Modelling Approaches to Examine Sugarcane Production Opportunities and Constraints, CSIRO, Brisbane, Australia, 1995, pp. 25-29.

[11] Martiné J.F., Modélisation de la croissance de la canne à sucre : méthodes de mesure, Cirad, St-Denis de la Réunion, 1995.

[12] Martiné J.F., Mosicas : modèle de fonctionnement et d'élaboration du rendement canne, paramétrage de la R 570, Cirad, St-Denis de la Réunion, 1996.
[13] Martiné J.F., Variabilité de la croissance et des potentialités de la canne à sucre à la Réunion : utilisation du modèle de croissance Mosicas, Proc. $4^{\mathrm{e}}$ congrès international Artas, Artas, Saint-Denis de la Réunion, 1998, 353-365.

[14] Mitchell P.L., Misuse of regression for empirical validation of models, Agric. Syst. 54 (1997) 313-326.

[15] Muchow R.C., Coates D.B., An analysis of the environmental limitation to yield of irrigated grain sorghum during the dry season in tropical Australia using a radiation interception model, Aust. J. Agric. Res. 37 (1986) 135-148.

[16] Muchow R., Spillman M.F., Wood A.W., Thomas M.R., Radiation interception and biomass accumulation in a sugarcane crop grown under irrigated tropical conditions, Aust. J. Agric. Res. 45 (1994) 37-49.

[17] Ono Y., Nakanishi T., Seasonal changes in growth and yield of sugarcane plants in Southwestern Islands of Japan, Jpn. J. Crop Sci. 52 (1983) 507-510.

[18] Robertson M.J., Keating B.A., Muchow R.C., APSIM-Sugar: its history conceptual basis, uses and wider applications, in: Proc. Research and Modelling Approaches to Examine Sugarcane Production Opportunities and Constraints, CSIRO, Brisbane, Australia, 1995, pp. 35-42.

[19] Robertson M.J., Wood A.W., Muchow R.C., Growth of sugarcane under high input conditions in tropical Australia. I. Radiation use, biomass accumulation and partitioning, Field Crops Res. 48 (1996) 11-25.

[20] Russell G., Absorbed radiation and crop growth, in: Varlet-Grancher C., Bonhomme R., Sinoquet H., (Eds.), Crop Structure and Light Microclimate: Characterization and Applications, Institut National de la Recherche Agronomique, Paris, 1993, pp. 459-470.

[21] Spitters C.J.T., Toussaint H.A.J.M., Goudriaan J., Separating the diffuse and direct component of global radiation and its implications for modeling canopy photosynthesis. Part I. Components of incoming radiation, Agric. For. Meteorol. 38 (1986) 217-229.

[22] Squire G.R., Marshall B., Terry A.C., Monteith J.L., Response to temperature in a stand of pearl millet, J. Exp. Bot. 35 (1984) 599-610.

[23] Van Dillewijn C., Botany of Sugarcane, Waltham Press, Waltham, MA, 1952.

[24] Varlet-Grancher C., Gosse G., Chartier M., Sinoquet H., Bonhomme R., Allirand J.M., Mise au point : rayonnement solaire absorbé ou intercepté par un couvert végétal, Agronomie, 9 (1989) 419-440.

[25] Vedie H., Étude de l'élaboration de l'indice foliaire de la canne à sucre, mémoire de DAA, Ensam, Montpellier, 1993. 